\title{
ANNOUNCEMENT
}

\section{Postdoctorate in Entomology}

The Department of Nematology and Entomology of the International Potato Center (CIP) announces a vacany for a postdoctoral position in Entomology.

\section{Job Requirements}

The candidate must have a Ph.D. degree in Entomology with a strong background in integrated management of insect pests. The candidate will work on the integrated management of potato tuber moth, Phthorimaea operculella (PTM) under field and storage conditions.

The job requires extending the use of IPM control technologies through on-farm trials. This will include the integration of cultural, biological and other methods of control. The position will be based in Tunis and involves international travel to co-operate in research and training activities with scientists of various national programmes, particularly in the countries of North Africa.

\section{Language Requirements}

Proficiency in English is indispensable. Knowledge of French and Arabic is desirable.

\section{Duration}

The position is for a period of 3 years.

Interested candidates should send their Curriculum Vitae and three letters of reference before February 28th, 1991 to:

Thrust Manager, IPM International Potato Center (CIP) Apartado 5969

Lima, Peru.

Telex: $25672 \mathrm{PE}$

Fax: (51) (14) 36-1570

E-Mail: 157: CG1801

157: CG1043 
Contents - continued from outside back cover]

S. E. RANDOLPH, D. J. ROGERS and J. KIHLU

J. O. A. DAVIES-COLE and
M. F. B. CHAUDHURY
M. OKECH and A. HASSANALI

R. K. SAINI

J. BRADY, M. J. PACKER and

G. GIBSON

R. H. GOODING

W. SHERENI

J. LANCIEN, J. MUGUWA,

C. LANNES and J. B. BOUVIER

E. A. OPIYO, A. R. NJOGU and

J.K. OMUSE

L. CLAUDE, E. JEAN-PIERRE,

G. PASCAL and L. JEAN-JACQUES

G. P. KAAYA and M. A. OKECH

A. P. M. SHAW

W. E. ORMEROD

Publisher's Announcement

Instructions to Authors

Author Checklist
347 Rapid changes in the reproductive cycle of wild-caught tsetse, Glossina pallidipes Austen, when brought into the laboratory

355 Mating efficiency in females of Glossina pallidipes

363 The origin of phenolic tsetse attractants from host urine: Studies on the pro-attractants and microbes involved

369 Responses of tsetse, Glossina spp. (Diptera: Glossinidae) to phenolic kairomones in a wind tunnel

377 Odour plume shape and host finding by tsetse

385 Genetic aspects of quality control in tsetse colonies

399 Strategic and tactical developments in tsetse control in Zimbabwe (1981-1989)

411 Tsetse and human trypanosomiasis challenge in south eastem Uganda

417 Use of impregnated targets for control of $G$. pallidipes in Kenya

427 The control of riverine tsetse

443 Microorganisms associated with tsetse in nature: Preliminary results on isolation, identification and pathogenicity

449 A spreadsheet model for the economic analysis of tsetse control operations benefiting cattle production

455 Africa with and without tsetse

462 Special Issues

i

iv 


\section{Insect Science and its Application}

The International Journal of Tropical Insect Science

VOLUME 11 NUMBER 3

1990

\section{CONTENTS}

\author{
r. R. ODHIAMBO \\ T. R. ODHIAMBO \\ J. K. GASHUMBA \\ J. H P. NYEKO, O. K. OLE-MOIYOI, \\ P. A. O. MAJIWA, L. H. OTIENO and \\ P. M. OC.IBA \\ L.. H. OTIENO, N. DARJ and \\ P. ONYANGO
}

D. B. MBULAMBERI

S. G. A. LEAK, C. COLLARDELLE,

i. COULIBALY, P. DUMONT, A. FERON,

P. HECKER, G. D. D'IETEREN, P. JEANNIN,

M. MINENGU, S. MINJA, W. MULATU,

G. NANKODABA, G. ORDNER,

G. J. ROWLANDS, B. SAUVEROCHE,

G. TIKIIBET and J. C. M. TRAIL

P. MILLIGAN

I. CHUKA MADUBUNYI

M. I. MWANGELWA, R. D. DRANSFIELD,

L. H. OTIENO and K. J. MBATA

J. W. HARGROVE

1). J. ROGERS
257 Preface

259 Keynote Address

265 Speciation and subspeciation in Nannomonas trypanosomes and their epidemiological significance

271 Characterization of trypanosome isolates from catule in Uganda using species-specific DNA probes reveals predominance of mixed infections

281 Electrophoretic analysis of Trypanosoma brucei sub-group stocks from cattle, tsetse and patients from Lambwe Valley, Western Kenya

289 Recent epidemic outbreaks of human trypanosomiasis in Uganda

293 Relationships between tsetse challenge and trypanosome prevalence in trypanotolerant and susceptible cattle

301 Modelling trypanosomiasis transmission

309 Ecological studies of Glossina austeni at Jozani Forest, Unguja Island, Zanzibar

315 Distribution and diel activity patterns of Glossina fuscipes fuscipes Newstead on Rusinga Island and mainland in Mbita, Kenya

323 Age-dependent changes in the probabilities of survival and capture of the tsetse, Glossina morsitans morsitans Westwood

331 A general model for tsetse populations 